PRZEGLĄD NAUK HISTORYCZNYCH 2019, R. XVIII, NR 2

http://dx.doi.org/10.18778/1644-857X.18.02.07

DROBNE PRACE I MATERIAEY

SŁAWOMIR BRALEWSKI

UNIWERSYTET ŁÓDZKI*

(iD) https://orcid.org/0000-0002-4708-0103

\title{
Siła i bezsilność cesarza Walensa, gorliwego chrześcijanina a zarazem wroga chrześcijan w ujęciu Sokratesa z Konstantynopola ${ }^{1}$
}

Streszczenie. Cesarza Walensa, sprawującego rządy w latach 364-378, łączy się przede wszystkim ze straszliwą i brzemienną w skutki klęską poniesioną przez wojska rzymskie w starciu z Gotami pod Adrianopolem 9 sierpnia 378 r., w której on sam poniósł śmierć. Chrześcijanie, zwolennicy nicejskiego credo z roku 325, odczytywali jego nagły zgon jako karę Bożą za prześladowanie prawowiernych chrześcijan, za których oni sami się uważali. Sokrates z Konstantynopola, autor Historii kościelnej, będącej kontynuacja dzieła Euzebiusza z Cezarei, dostrzegł w postępowaniu cesarza Walensa sprzeczność. Historyk ów widział w nim zarówno zagorzałego chrześcijanina, który w swej wierze kierował się gorliwościa, jak i wroga chrześcijan, prowadzącego przeciwko nim wojnę. Sprzeczność tę Sokrates kładł na karb samego władcy, który choć przekonany o swej wielkiej gorliwości religijnej, za nic miał zasady religii chrześcijańskiej, którymi winien się kierować. Jeśli chodzi natomiast o tytułowa siłę i bezsilność, to stwierdzić trzeba, że w przekonaniu Sokratesa $z$ Konstantynopola siła cesarza Walensa była tylko pozorna, choć na jego rozkaz przelano niemało chrześcijańskiej krwi. Bezsilność wspomnianego władcy obnażyli najpierw sami prześladowani przez niego chrześcijanie, a ostatecznie uczynił to sam Bóg, zsyłając na Imperium Romanum różnorakie kataklizmy, a na samego Walensa śmierć niegodną cesarza bez należnego mu pochówku.

Słowa kluczowe: cesarz Walens, Sokrates z Konstantynopola, bitwa pod Adrianopolem.

* Wydział Filozoficzno-Historyczny, Instytut Historii, Katedra Historii Bizancjum, e-mail: slawomir.bralewski@uni.lodz.pl

1 Artykuł powstał w związku z Ogólnopolska Konferencją Starożytniczą Siła $i$ bezsilność władzy, zbiorowości i jednostki $w$ świecie grecko-rzymskim i bizantyńskim, która odbyła się w Lublinie w dniach 18-19 V 2017 r. 
esarza Walensa, sprawujaccego rządy w latach 364-378, łączy się przede wszystkim ze straszliwą i brzemienna w skutki klęska poniesiona przez wojska rzymskie w starciu $z$ Gotami pod Adrianopolem 9 sierpnia 378 r., w której on sam poniósł śmierć2. Chrześcijanie, zwolennicy nicejskiego credo z roku 325, odczytywali jego nagły zgon jako karę Bożą za prześladowanie prawowiernych chrześcijan, za których oni sami się uważali. Trzeba jednak pamiętać, że sam Walens był również chrześcijaninem, ale skłaniającym się $\mathrm{ku}$ arianizmowi ${ }^{3}$. Chrześcijanie zatem tym razem cierpieli prześladowania nie ze strony pogan, ale swoich współwyznawców. Jak się wydaje, Walens był zarówno silną, jak i złożoną osobowością. Dostrzegał to już wyznawca tradycyjnych kultów Ammian Marcellin, wskazując na jego cnoty i wady, w których można widzieć $z$ jednej strony jego siłę, a $z$ drugiej słabość, a nawet bezsilność. Do pierwszych zaliczył wierność i stałość władcy w przyjaźni, surowe zwalczanie nadużyć urzędników, korupcji czy defraudacji państwowego majątku, przestrzeganie twardej

2 Timothy D. Barnes (The Collapse of the Homoeans in the East, „Studia Patristica” 1997, vol. XXIX, s. 3) uznał starcie pod Adrianopolem za jedna z decydujących bitew w dziejach ludzkości. Marek Wilczyński (Germanie $w$ służbie zachodniorzymskiej $w V w$. n.e., Oświęcim 2018, s. 484, przyp. 6) wskazywal zaś na nieodwracalne skutki klęski pod Adrianopolem, zmieniające oblicze dziejów późnorzymskich do tego stopnia, że niektórzy z badaczy byli skłonni uznać dzień wspomnianej bitwy za koniec starożytności. Por. też T.S. Bu rn s, The Battle of Adrianople: A Reconsideration, „Historia. Zeitschrift für alte Geschichte” 1973, Bd. XXII, H. 2, s. 336-345; B. Ru tow s ki, Bitwa pod Adrianopolem (9 VIII 378 r.) i jej następstwa, „Meander” 1978, R. XXXIII, s. 525-539; N. Le n s ki, Initium mali Romano imperio: Contemporary Reactions to the Battle of Adrianople, "Transactions of the American Philological Association" 1997, vol. CXXVII, s. 129-168; S. Willia m s, G. Frie11, Theodosius the Empire at Bay, London 2005, s. 152-156.

${ }^{3}$ Weług Sokratesa $z$ Konstanty no pola (Historia ecclesiastica, dalej: HE, IV 1 - Kirchengeschichte, hrsg. G.C. Hansen, Berlin 1995), S oz o me na (HE, VI, 6, 10 - Kirchengeschichte, hrsg. J. Bidez, G.Ch. Hansen, Berlin 1995), T e o d o r e ta z Cyru (HE, IV, 12 - Kirchengeschichte, hrsg. L. Parmentier, G.Ch. Hansen, Berlin-New York 2009) Walens był arianinem. Rufin z Akwilei (HE, II 2 - Kirchengeschichte, hrsg. E. Schwartz, T. Mommsen, F. Winkelmann, Berlin 1999) nazywa go heretykiem. W przekonaniu Hieronima ze Strydonu (Chronicon a. 367, hrsg. R. Helm, Berlin 1956) miał zostać ochrzczony przez arianina Eudoksjusza, biskupa Konstantynopola. Henri-Irénée Marrou (L'Église de l'Antiquité tardive 303-604, Paris 1985, s. 51) dowodził, że Walens przybrał pozę teologa i opowiadał się za złagodzonym arianizmem, popierając homejskie credo przyjęte na synodzie w Konstantynopolu w roku 360. Robert Devrees se (Le patriarcat d'Antioche depuis la paix de l'Église jusqu'à la conquête arabe, Paris 1945, s. 24) natomiast wskazywał na kontynuacje przez Walensa polityki religijnej cesarza Konstancjusza II. 
dyscypliny w służbie wojskowej i cywilnej oraz troskę o prowincje i umiarkowany fiskalizm ${ }^{4}$. Do wad Walensa Ammian Marcellin zaliczył chciwość władcy, dybiącego na życie i mienie możnych ludzi, dawanie nazbyt łatwo posłuchu oskarżeniom, także tym fałszywym, niesprawiedliwość, skłonność do okrucieństwa i gniewu, prostacką umysłowość, brak wykształcenia. W dodatku Ammian Marcellin zarzucał mu opieszałość i lenistwo ${ }^{5}$. Cnoty i wady Walensa - jego siła i bezsilność odnoszą się zatem w wydaniu Ammiana Marcellina do mocnej i słabej strony jego charakteru i bywa, że stanowia nawet antytezę, skoro $z$ jednej strony cesarz ów zmniejszał wszelkie ciężary danin i nie pozwalał podwyższać podatków, a $z$ drugiej był nieumiarkowany w dążeniu do wielkiego bogactwa i szukał korzyści i zysku6 ${ }^{6}$.

Wydaje się, że chrześcijanin Sokrates z Konstantynopola, autor Historii kościelnej, będącej kontynuacją dzieła Euzebiusza z Cezarei, dostrzegł w postępowaniu cesarza Walensa jeszcze dalej idaca sprzeczność ${ }^{7}$. Historyk ów, charakteryzując Walensa, nie tylko pisał o jego wadach i zaletach, ale wręcz kreował swoista antytezę, widząc w nim zarówno zagorzałego chrześcijanina, który w swej wierze kierował się gorliwościa $(\zeta \tilde{\eta} \lambda o \varsigma)^{8}$, jak i wroga chrześcijan,

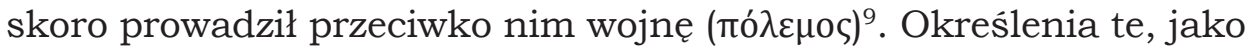
ze sobą sprzeczne, wydaja się wzajemnie wykluczać. W jaki sposób zatem rozumiał je Sokrates, odnosząc obydwa do tego samego władcy? Czy on również dostrzegał w działaniach władcy czyny, które były wyrazem siły i bezsilności zarazem?

\section{Gorliwość chrześcijańska cesarza Walensa w ujęciu Sokratesa}

Według definicji słownikowej wyrażenie „gorliwość” oznacza zapalczywość, żarliwość, wytrwałość, zapał, zaangażowanie, a człowiek gorliwy wykazuje w czymś dużo pilności i zapału. Grecki termin $\zeta \tilde{\eta} \lambda$ oৎ odnosi się nie tylko do gorliwości, skwapliwości, wielkiego pragnienia czegoś i intensywnego zabiegania o coś, lecz także do

${ }^{4}$ Ammianus Marcellinus, Rerum gestarum libri qui supersunt, XXXI, 14, 1-4, hrsg. C.V. Clark, Bd. II, Berlin 1915.

${ }^{5}$ Ammianus Marcellinus, Rerum gestarum, XXXI, 14, 5-9.

${ }^{6}$ Ammianus Marcellinus, Rerum gestarum, XXXI, 14, 2 i 5.

7 Sokrates czwartą księgę swej Historii kościelnej poświęcił panowaniu Walentyniana I i jego brata Walensa.

8 Socrates, HE, IV, $1,7$.

9 Socrates, HE, IV, 35, 3. 
rywalizacji i współzawodnictwa, zazdrości, a nawet gwałtowności ${ }^{10}$. Do gorliwości w sferze religijnej Sokrates przykładał duże znaczenie. Przypisywał ja Konstantynowi Wielkiemu, do którego odnosił się $z$ wielką atencja ${ }^{11}$. W jego relacji władca ów w sprawach dotyczacych prawowierności wykazywał troskę ( $\sigma \pi 0 u \delta \eta ́) ~ i ~ g o r l i w o s ́ c ́ ~(\zeta \tilde{\eta} \lambda o \varsigma)$. Przejęty duchem religii chrześcijańskiej zaś $z$ wielką ochotą, za-

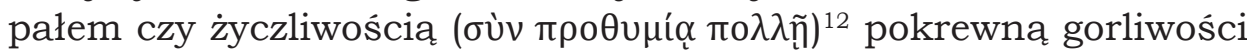
znosił prześladowania chrześcijan, odwoływał z zesłania wygnańców, wypuszczał na wolność uwięzionych, zwracał skonfiskowane mienie prywatne, podnosił $z$ ruin kościoły ${ }^{13}$. W późniejszym czasie natomiast, jak podkreślał Sokrates, troszcząc się $z$ gorliwościa

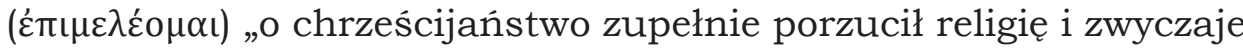
pogańskie" 14 .

Jeśli chodzi zaś o cesarza Walensa, to Sokrates już na początku czwartego rozdziału swej Historii kościelnej poświęconego panowaniu cesarzy Walentyniana I i Walensa wskazywał na gorliwość religijna obydwu wspomnianych władców. Zaznaczając jednak, że chociaż jeden i drugi byli chrześcijanami, to różnili się w chrze-

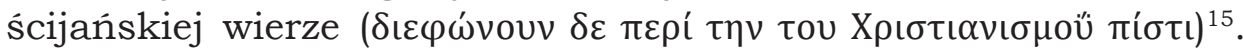
Walentynian bowiem wyznawał wiarę soboru nicejskiego, a Walens

10 Słownik języka polskiego, red. W. Doroszewski, t. II, Warszawa 1960, s. 1237-1238, s.v. gorliwość, gorliwy; A Greek-English Lexicon, eds H.G. Liddell,

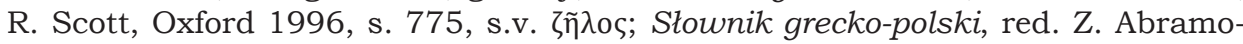

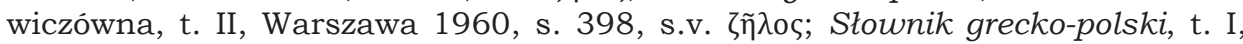
oprac. O. Jurewicz, Warszawa 2000, s. 423, s.v. $\zeta \tilde{\eta} \lambda$ os.

${ }^{11} \mathrm{Na}$ temat panowania cesarza Konstantyna napisano bardzo wiele. Do najciekawszych monografii wydanych ostatnio należa niewatpliwie: H.A. Drake, Constantine and the Bishops: the Politics of Intolerance, Baltimore 2000; A. M arcone, Costantino il Grande, Roma-Bari 2000; Ch.M. Odah1, Constantine and the Christian Empire, London-New York 2004; The Cambridge Companion to the Age of Constantine, ed. N. Lenski, Cambridge 2006; K.M. Girardet, Der Kaiser und sein Gott. Das Christentum im Denken und in der Religionspolitik Konstantins der Grosse, Berlin-New York 2010; T.D. Barnes, Constantine. Dynasty, Religion and Power in the Later Roman Empire, Oxford 2011; P. Marava1, Constantin, empereur romain et chrétien, Paris 2011; B. Lançon, T. Moreau, Constantin. Un Auguste chrétien, Paris 2012.

12 Socrates, HE, I, 2, 9.

13 Socrates, HE, I, 2-3.

${ }^{14}$ Socrates, HE, I, 18, 1; tłum. S. Kazikowski, s. 112. Literatura przedmiotu na temat konwersji Konstantyna na chrześcijaństwo jest niezwykle bogata, por. S. Bralewski, Symmachia Cesarstwa Rzymskiego z Bogiem chrześcijan (IV-VI wiek), t. I („Niezwykła przemiana” - narodziny nowej epoki), Byzantina Lodziensia XXVII, Łódź 2018, s. 25-70.

${ }^{15}$ Socrates, HE, IV 1, 5. 


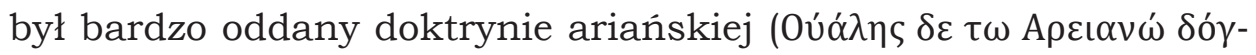

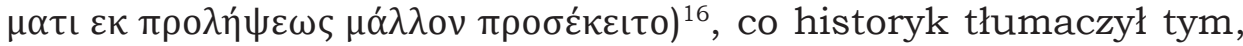
że otrzymał chrzest $z$ rąk Eudoksjusza, przywódcy arian w Konstantynopolu ${ }^{17}$.

Świadomość tych różnic nie przeszkodziła Sokratesowi uznawać, że obydwaj, „w zakresie swej wiary, odznaczali się wielką gorliwością"18. Sokrates przytoczył nawet dowód na gorliwość wiary obydwu. Wskazywał, że za rządów Juliana, kiedy zmuszano ich do złożenia ofiary, „woleli wyrzec się służby wojskowej niż porzucić religię Chrystusowa" ${ }^{19}$. Ponieważ jednak, wedle Sokratesa, potrzebni byli państwu, nie usunięto ich $z$ wojska. Ciekawe, że w adekwatnym fragmencie w swym dziele Sozomen, opierajacy się w znacznej mierze w swej narracji na relacji Sokratesa, kwestie gorliwości religijnej Walensa pominąl całkowicie. W jego Historii kościelnej jest mowa jedynie o heroicznej postawie Walentyniana, który za przyznanie się do wyznawania chrześcijaństwa miał jednak zapłacić dożywotnim wygnaniem do Meliteny w Armenii. Sozomen podkreślał fakt, że obydwaj władcy byli chrześcijanami ${ }^{20}$.

W przekonaniu Sokratesa sam Walens miał uważać się za wzór

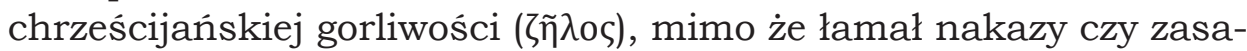
dy religii chrześcijańskiej, mordując $z$ błahego powodu swych poddanych $^{21}$. Historyk dostrzegać miał zatem wyraźna sprzeczność między postępowaniem cesarza a jego samoświadomością.

\section{Wrogość cesarza Walensa wobec chrześcijan w ujęciu Sokratesa}

Temu wątkowi Sokrates, zajmując się dziejami Kościoła w okresie panowania cesarza Walensa, poświęcił najwięcej miejsca. Dając już na początku IV księgi charakterystykę porównawczą Walentyniana i Walensa, wskazywał, że: ,jako cesarze, w zakresie troski o sprawy państwa $z$ początku podobni byli do siebie nawzajem; natomiast na gruncie wiary chrześcijańskiej, mając, [...] odmienne poglądy,

16 Socrates, HE, IV 1, 5. Por. N. Lenski, Failure of Empire: Valens and the Roman State in the Fourth Century A.D., Berkeley-Los Angeles-London 2002, s. 242-263.

17 Socrates, HE, IV 1, 6.

18 Socrates, HE, IV 1, 7, tłum. S. Kazikowski, s. 330.

19 Socrates, HE, IV 1, 9, tłum. S. Kazikowski, s. 330. Por. S. Bradbury, Julian's Pagan Revival and the Decline of Blood Sacrifice, "Phoenix” 1995, vol. XLIX, No. 4, s. 341-356.

20 Sozomenus, HE, VI 6.

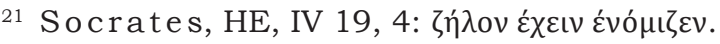


w całkowicie różny sposób odnosili się do wyznawców chrystianizmu. Walentynian bowiem popierał wprawdzie swoich współwyznawców, bynajmniej jednak nie gnębił arian. Walens zaś, pragnąc za wszelką cenę rozkrzewić arianizm, potwornych dopuścił się czynów wobec zwolenników odmiennych przekonań"22. Postępowanie Walensa, wedle Sokratesa, wynikało więc $z$ chęci zaprowadzenia jedności na gruncie doktrynalnym wśród wyznawców Chrystusa na podstawie założeń nauki ariańskiej. Idea religijnej jedności czy jedności w kulcie w ówczesnej epoce była zaś wartościa podstawową, warunkująca, jak mniemano, powszechna pomyślność dzięki wsparciu Jedynego Boga, jak wierzyli chrześcijanie, czy szerzej sił nadprzyrodzonych, o co zabiegali poganie. O wysiłkach chrześcijan i samych władców podejmowanych w celu przywrócenia jedności Kościoła Sokrates pisał wielokrotnie. Okrucieństwo Walensa, zabiegającego o tę jedność, jak się wydaje, w odczuciu Sokratesa, przekroczyło dopuszczalne normy. Wplótł on więc do swej narracji wywód słynnego w owych czasach filozofa Temistiusza ${ }^{23}$, który w mowie zwanej „Dedykacyjną” ${ }^{24}$ miał wskazywać władcy, że wśród pogan występuje nieporównanie większa różnorodność opinii na temat świata nadprzyrodzonego niż u chrześcijan. Dowodził też, że „Bóg pragnie odbierać tak różnorodnie oddawaną Mu cześć, bo chce, aby każdy $z$ większym uszanowaniem i bojaźnia odnosił się do Jego Majestatu, ponieważ niełatwo jest Go poznać"25. Mimo że Sokrates nie skomentował wywodu Temistiusza, konkluzja, jaka chciał przekazać, narzuca się sama: Bóg zadowolony jest $z$ owej różnorodności i nie wymaga od swych wyznawców jednomyślności na swój temat.

Walens jednak, w przekonaniu Sokratesa, prowadził o tę jedność wojnę, która stała się wojną $z$ samym chrześcijaństwem. Pisał o tym wprost, wspominając, że kiedy cesarz szykował się do wojny

${ }^{22}$ Socrates, HE, IV 1, 11-13; tłum. S. Kazikowski, s. 330.

${ }^{23}$ Na temat Temistiusza por. P. Heather, D. M o n cur, Politics Philosophy and Empire in Fourth Century Select Orations of Themistius, Liverpool 2001, s. 1-42.

${ }^{24}$ Mowa ta się nie zachowała. Por. P. Heather, D. Moncur, Politics Philosophy..., s. 201.

${ }^{25}$ Socrates, HE, IV 32, tłum. S. Kazikowski, s. 382-383. Opinia Temistiusza miała przyczynić się do złagodzenia postępowania władcy, który „zamiast wydawać wyroki śmierci wymierzał kapłanom karę wygnania”. Por. też Sozome nus, HE, VI, 36-37. Według Noela Len skiego (Failure of Empire: Valens and the Roman State in the Fourth Century A.D., Berkeley-Los Angeles-London 2002, s. 212) wygłaszając wspomnianą mowę, Temistiusz miał nadzieję uzyskać od cesarza Walensa także tolerancję dla pogan. 
z Gotami i musiał opuścić Antiochię w celu udania się do Konstantynopola, „ucichła wojna, jaka prowadził tam przeciwko chrześcijaństwu" ${ }^{26}$. Wyraźnie zatem w tym przypadku Sokrates utożsamił zwolenników nicejskiego credo ogólnie $z$ religią chrześcijańska, co nie znaczy jednak, że opowiadających się za doktryną ariańska nie uważał za chrześcijan. Widać to chociażby we wspomnianym już fragmencie, w którym pisał o Walentynianie i Walensie jako o chrześcijanach, mimo że różnili się w chrześcijańskiej wierze, skoro pierwszy $z$ nich stawał po stronie nicejczyków, a drugi $\operatorname{arian}^{27}$. Wydaje się, że kluczowa dla Sokratesa była postawa cesarza Walensa, który postępujac wbrew nakazom i zasadom religii chrześcijańskiej, prześladował i pozbawiał życia swych poddanych, czyniac to $\mathrm{w}$ dodatku $\mathrm{z}$ pobudek religijnych ${ }^{28}$. W przekonaniu Sokratesa zatem Walens, mimo że sam uważał się za chrześcijanina, swoimi uczynkami swemu chrześcijaństwu zaprzeczał. Toteż historyk określał podjęte przez władce prześladowania nicejczyków mianem wojny wypowiedzianej wyznawcom Chrystusa.

Władca miał ją prowadzić od początku swych rządów. Kiedy ze strony Persów zapanował spokój, Walens przebywający w Antiochii, w gotowości odparcia ewentualnego ich najazdu, jak wskazywał Sokrates, „na złe wykorzystał tę ciszę i podjał nieubłagana walkę $z$ wyznawcami wiary we wspólistotność"29. W mieście tym pousuwał $z$ Kościołów wszystkich przeciwników wspomnianego Eudoksjusza, karząc ich grzywnami i nakładając na nich różnorodne sankcje. Wielu $z$ nich wówczas miało nawet znaleźć śmierć w nurtach Orontesu ${ }^{30}$. Podczas swego drugiego pobytu w Antiochii (rok 370) Walens zaostrzyć miał represje stosowane wobec przeciwników arianizmu ${ }^{31}$. W przekazie Sokratesa władca nie zadowolił się

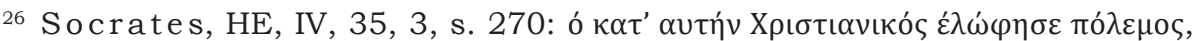
tłum. S. Kazikowski, s. 385. John H.W.G. Liebeschuetz (Antioch, City and Imperial Administration in the Later Roman Empire, Oxford 1972, s. 128) przypuszczał, że bunt antiocheńczyków przeciwko Walensowi mógł być wywołany niedoborami żywności w mieście.

27 Socrates, HE, IV 1, 5.

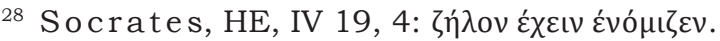

${ }^{29}$ Socrates, HE, IV 2, tłum. S. Kazikowski, s. 331. Por. R. Snee, Valens' Recall of the Nicene Exiles and Anti-Arian Propaganda, "Greek, Roman, and Byzantine Studies" 1985, vol. XXVI, s. 395-419.

30 Socrates, HE, IV 2.

${ }^{31}$ Wedle Johna H.W.G. Liebeschuetza (op. cit., s. 210-211) wystapienia mieszkańców Antiochii przeciwko cesarzowi Walensowi miały personalny charakter związany z jego proariańska polityka i zwalczaniem zwolenników Melecjusza, 
usunięciem $z$ Kościołów niemal we wszystkich miastach Wschodu wyznawców współistotności, ale maltretował ich, poddawał rozmaitym kaźniom, a przy tym „wygubił jeszcze więcej ludzi aniżeli poprzednio, wydając ich na pastwę rozmaitych rodzajów śmierci, a szczególnie na śmierć przez utopienie w rzece"32.

Walens usuwał wyznawców wiary we współistotność także $z$ Konstantynopola, a razem $z$ nimi także nowacjan, „obrońców tych samych dogmatów". Zamkną ich kościoły, a ich biskupa skazał na wygnanie $^{33}$. Kiedy po śmierci Eudoksjusza zwolennicy credo nicejskiego próbowali wprowadzić na biskupi tron Konstantynopola Ewagriusza, konsekrowanego przez Eustacjusza, byłego biskupa Antiochii, jeden i drugi zostali skazani na wygnanie, a wierni ortodoksyjnego Kościoła byli bici, znieważani, zamykani w więzieniach, karani grzywną. Jak skonstatował Sokrates, dopuszczano się wobec nich wszelkich okrucieństw ${ }^{34}$. Szczególnie okrutnie została potraktowana delegacja 80 przedstawicieli duchowieństwa wysłanych $z$ Konstantynopola do cesarza przebywajaccego w Nikomedii, aby wyprosić złagodzenie represji. Pisemnie informowali władcę o gwałtach i bezmiarze cierpienia, jakie na nich spadły, być może sąząc, że ten nie jest ich świadom. Cesarz jednak, rozsierdzony ich oporem, nakazał ukarać ich śmiercią. W obawie przed reakcja tłumu, prefekt Modest wykonujacy ów rozkaz, pozorujac wysłanie ich na wygnanie, rozkazał podpalić na morzu okręt, którym ci mieli płynać na miejsce swego oddalenia, i w ten sposób pozbawił ich $\dot{z} y c i a^{35}$.

Kiedy Walens zorientował się, że pielgrzymi przybywający do bazyliki św. Tomasza Apostoła w Edessie wrogo odnosili się „do wyznawanej przez niego herezji”, polecił ukarać ich śmiercią i tylko determinacja pielgrzymów sprawiła, że cesarz cofnął wydane rozkazy ${ }^{36}$.

jednego z ówczesnych biskupów Antiochii. Por. F. Cavallera, Le schisme d'Antioche, Paris 1905, s. 131-155. Na temat schizmy antiocheńskiej por. też S. Bralew ski, Kanony kościelne $w$ sporze między Wschodem a Zachodem na tle schizmy antiocheńskiej w IV wieku, „Acta Universitatis Lodziensis. Folia Historica” 2005, nr 80 , s. $27-42$.

${ }^{32}$ Socrates, HE, IV 17, tłum. S. Kazikowski, s. 353.

${ }^{33}$ Socrates, HE, IV 9, tłum. S. Kazikowski, s. 339.

${ }^{34}$ Socrates, HE, IV 15, tłum. S. Kazikowski, s. 351.

${ }^{35}$ Socrates, HE, IV 16, tłum. S. Kazikowski, s. 351.

${ }^{36}$ Socrates, HE, 18, tłum. S. Kazikowski, s. 354. 
W relacji Sokratesa na pisemne polecenie cesarza Walensa prefekt Aleksandrii Palladiusz użył wojska przeciwko Piotrowi, następcy Atanazego na biskupim tronie Aleksandrii i jego zwolennikom. $\mathrm{W}$ ten sposób Piotr znalazł się $\mathrm{w}$ więzieniu, duchowni $z$ jego otoczenia na wygnaniu, a ariański biskup Lucjusz $z$ ich pomoca obją biskupia siedzibę w Aleksandrii ${ }^{37}$, gdzie potem na mocy zarządzenia cesarskiego nakazano pousuwać z obszaru całego Egiptu wyznawców wiary we współistotność. W świetle przekazu Sokratesa „prefekt otrzymał polecenie, aby z pomoca licznych oddziałów wojska wyganiał zewsząd tych, których tylko wskaże Lucjusz. Rabowali wówczas klasztory na odludziu, zakłócając ich spokój i urządzając formalne najazdy. Zbrojnie nachodzacc ludzi bezbronnych i nie zamierzających nawet gołej ręki wyciagnąć dla zadania ciosu, tak nielitościwie ich łupili, że słowo ludzkie oddać nie jest w stanie cierpień, na jakie skazani byli ci nieszczęśliwcy"38.

W przekonaniu Sokratesa wraz $z$ ogłoszeniem przez cesarza Walensa ustawy skazującej na wygnanie ortodoksów w Aleksandrii i w całym Egipcie „zniszczony został i legł w gruzach cały porzadek. [...] jednych wleczono przed trybunały, drugich wtracano do więzień, każdego na inny torturowano sposób. Przeróżne bowiem kary stosowano wobec tych, co umiłowali spokojny tryb życia"39. Użycie przeciwko chrześcijanom wojska i zastosowana przemoc, pociagająca za sobą wiele ofiar, w tym śmiertelnych, połączona $z$ rabunkiem i zniszczeniem dóbr materialnych, kreowały obraz prawdziwej wojny, a $z$ jej inicjatora czyniły wroga chrześcijan.

\section{Bezsilność cesarza Walensa w ujęciu Sokratesa}

Niemoc, tytułową bezsilność cesarza Walensa i fiasko zastosowanej przez niego siły obnażyli sami chrześcijanie. W relacji Sokratesa uczynili to najpierw wspomniani pielgrzymi przybywający do bazyliki św. Tomasza Apostoła w Edessie, którzy ostrzeżeni przez prefekta o grożącej im śmierci tłumnie przybywali wraz z dziećmi do bazyliki, chcąc być godnymi zaszczytu męczeństwa. Wobec

\footnotetext{
${ }^{37}$ Socrates, HE, IV, 21.

38 Socrates, HE, IV, 22, tłum. S. Kazikowski, s. 357-358. Por. N. Len ski, Failure of Empire..., s. 255-257.

39 Socrates, HE, IV, 24, 1; tłum. S. Kazikowski, s. 366; N. Len ski, Valens and the Monks: Cudgeling and Conscription as a Means of Social Control, „Dumbarton Oaks Papers" 2004, vol. LVIII, s. 95-103.
} 
determinacji zgromadzonych tłumów prefekt, który miał być wykonawca cesarskiego rozkazu, przekonał władcę do jego cofnięcia. Sokrates znamiennie skonstatował wspomniane wydarzenie: „W ten sposób Edesseńczycy zdołali uniknąć zbrojnego najścia i podboju ze strony własnego cesarza"40. Determinacja zatem, wydawałoby się, bezsilnych okazała się ich siłą i czyniła bezsilna siłę władcy. $Z$ antytezy robi się więc antylogia czy oksymoron.

Podobnie bezsilność cesarza obnażyli egipscy mnisi. Zostali oni zaatakowani przez „wielkie mnóstwo żołnierzy"41 i tłumy zmobilizowane przez Lucjusza, ariańskiego biskupa Aleksandrii, niemające „żadnej litości dla rzeszy świętych mężów”, mimo że ci zajęci byli „swą codzienna pracą: modlitwą, leczeniem chorych, wypędzaniem złych duchów”42. Jak jednak zaznaczył Sokrates, „można się było spodziewać”, że Opatrzność Boża nie dopuści, „aby te cierpienia stały się udziałem tych mężów, ponieważ coś znaczniejszego miała w swych planach: aby ich straszne cierpienia utorowały innym droge do zbawienia w Bogu. Ostateczny rezultat wydarzeń, zdaniem Sokratesa, w pełni okazał te prawdę. Kiedy owi godni podziwu mężowie okazali się silniejsi ponad środki przymusu, jakie wobec nich stosowano" ${ }^{\prime 3}$. Ponownie pozorna słabość przekuta została w moc, a realna siła okazała się $z$ woli samego Boga siłą pozorną.

Sokrates $z$ Konstantynopola, kierując się filozofią dziejów zakładająca współzależność od siebie dwóch porządków: państwowego i kościelnego ${ }^{44}$, wskazywał na gniewna reakcję samego Boga wywołana przez poczynania Walensa. W jego relacji 2 lipca 367 r. w Konstantynopolu spadł „grad wielkości kurzego jaja, twardy jak kamień"45. I choć w sposób jednoznaczny nie zinterpretował tego

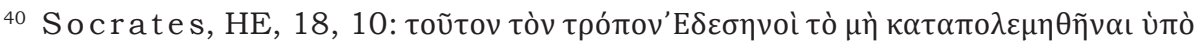

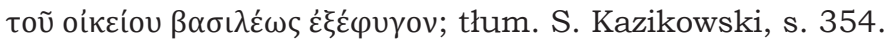

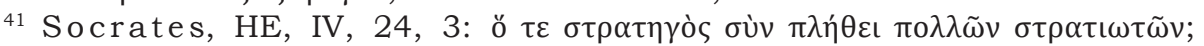
tłum. S. Kazikowski, s. 366.

${ }^{42}$ Socrates, HE, IV, 24, tłum. S. Kazikowski, s. 366-367.

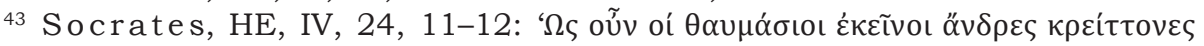

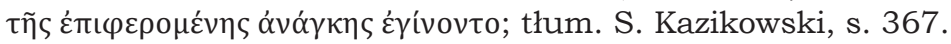

${ }^{44}$ W swej historiozofii Sokrates odwoływał się do antycznych koncepcji opartych na tradycyjnych wierzeniach $-z$ jednej strony do kosmicznej sympathei, czyli zależności wzajemnej i oddziaływania na siebie poszczególnych składowych kosmosu, a $z$ drugiej do losu (tyche), znajdującego się pod wpływem kairoi, czyli różnorodnych, przełomowych wydarzeń i chwil. Inaczej niż w wyobrażeniach pogańskich w schrystianizowanej formie wspomnianych idei los nie był ślepy, gdyż nieszczęśliwe kairoi były konsekwencją ludzkich przewinień.

45 Socrates, HE, IV, 11, 1; tłum. S. Kazikowski, s. 340. 
wydarzenia, powoływał się na opinię publiczną, informując, że „wielu mówiło, że grad zesłany na ziemię był znakiem gniewu Bożego, jako że cesarz skazał na wygnanie wielu spośród poświęconych Bogu mężów, którzy nie chcieli się połączyć z Eudoksjuszem"46. Bardziej zdecydowanie wypowiedział się w przypadku trzęsień ziemi, jakie nawiedziło Bitynię 11 października 367 r. i zniszczyło Niceę, i kolejne, które nastapiło niedługo po pierwszym i zrujnowało w znacznym stopniu miasto Germe na Hellesponcie ${ }^{47}$. Sokrates ze zdziwieniem konstatował, że wydarzenia te nie wznieciły żadnego niepokoju w sercach Eudoksjusza czy cesarza Walensa, skoro nie zrezygnowali $z$ dalszych prześladowań „tych, którzy myśleli inaczej niż oni” ${ }^{48}$. W przekonaniu historyka: „To co się działo w związku $z$ trzęsieniami ziemi, wydawało się widocznym znakiem zamętu, jaki panował w życiu kościelnym"49.

Podobnie spalenie na okręcie duchownych konstantynopolitańskich miało nie pozostać bez kary, choć i tym razem nie była to opinia bezpośrednio wyrażona przez Sokratesa, ale przez opinię

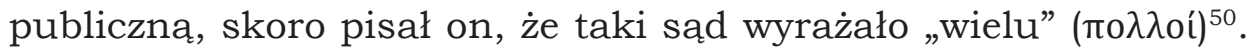
Ostatecznie jednak słabość polityki Walensa i rzeczywista jej ocenę przez Boga obnażyła jego śmierć - niegodna cesarza oraz losy jego ciała po śmierci, które, jak wydaje się sugerować Sokrates, nie doczekało się należytego władcy pochówku ${ }^{51}$.

Konkludując, trzeba więc podkreślić, że w przekonaniu Sokratesa $z$ Konstantynopola siła cesarza Walensa była tylko pozorna,

${ }^{46}$ Socrates, HE, IV 11, 2; tłum. S. Kazikowski, s. 340.

47 Socrates, HE, IV $11,5$.

48 Socrates, HE, IV 11, 6; tłum. S. Kazikowski, s. 341.

${ }^{49}$ Socrates, HE, IV 11, 7; tłum. S. Kazikowski, s. 341.

50 Socrates, HE, IV 16, 7; tłum. S. Kazikowski, s. 351.

51 Socrates, HE, IV 38, 7-11. Sokrates przytaczał dwie relacje na temat śmierci cesarza. Według jednych władca zginać miał w ogniu, kiedy próbował znaleźć schronienie w jakiejś osadzie, a wedle innych polec miał, walczac jak piechur bez cesarskich insygniów. Podobnie opisywał jego śmierć Ammian Marcellin (Rerum gestarum, XXXI, 13, 12-17), wedle którego cesarz padł przeszyty strzała wśród zwykłych żołnierzy bądź też spłonął w wieśniaczej chacie. Por. też Hie ronymus, Chronicon a. 378; Rufinus, HE, II, 13; Philostorgius, HE, IX 17; Sozomenus, HE, VI 40, 2-5; Theodoretus, HE, IV 37, 2. Dla Ambrożego z Mediolanu (De fide, II, 141-142) śmierć Walensa była karą za prześladowanie ortodoksów. Natomiast Libaniusz (Orationes, 24, 4) dowodził, że Walens zginął, walcząc na koniu. Noel Len ski (Initium..., s. 152) zwrócił uwagę, że niemal natychmiast po klęsce pod Adrianopolem w Konstantynopolu powiązano śmierć cesarza $z$ jego arianizmem i prześladowaniami zwolenników nicejskiego credo, ale także $z$ prześladowaniem pogan (s. 163). 
choć na jego rozkaz przelano niemało chrześcijańskiej krwi. Bezsilność wspomnianego władcy obnażyli najpierw sami prześladowani przez niego chrześcijanie, jak choćby pielgrzymi przybywający do bazyliki św. Tomasza Apostoła w Edessie czy egipscy mnisi, a ostatecznie uczynił to sam Bóg, zsyłając na Imperium Romanum różnorakie kataklizmy. Najwyraźniejszym przejawem gniewu Bożego była zaś śmierć Walensa niegodna cesarza i brak należnego władcy pochówku. Natomiast sprzeczność związaną z chrześcijańską gorliwościa cesarza Walensa i jego wrogościa wobec chrześcijan Sokrates składał na karb samego władcy, który choć przekonany o swej wielkiej gorliwości religijnej, za nic miał zasady religii chrześcijańskiej, którymi winien się kierować.

\section{Bibliografia}

\section{Ź RÓDEA DRUKOWANE}

Ambrosius, De fide ad Gratianum Augustum, [w:] Patrologiae cursus completus,

Series latina, vol. XVI, ed. J.-P. Migne, Paris 1880, kol. 527-698.

Ammianus Marcellinus, Rerum gestarum libri qui supersunt, hrsg. C.V. Clark, Bd. I-II, Berlin 1910-1915.

Hieronymus, Chronicon, hrsg. R. Helm, Berlin 1956.

Libanios, Orationes - Libanii opera, rec. R. Foerstere, vol. I-IV, Lipsiae 1903-1908. Philostorgius, Kirchengeschichte, hrsg. J. Bidez, bearb. F. Winkelmann, Berlin 1981. Rufinus, Kirchengeschichte, [w:] Eusebius Werke, Die Kirchengeschichte, hrsg.

E. Schwartz, T. Mommsen, F. Winkelmann, Berlin 1999, s. 957-1040.

Socrates, Kirchengeschichte, hrsg. G.C. Hansen, Berlin 1995.

Sokrates Scholastyk, Historia Kościoła, tłum. S. Kazikowski, wstęp E. Wipszycka, kom. A. Ziółkowski, Warszawa 1986.

Sozomenus, Kirchengeschichte, hrsg. J. Bidez, G.Ch. Hansen, Berlin 1995.

Theodoret, Kirchengeschichte, hrsg. L. Parmentier, G.Ch. Hansen, Berlin-New York 2009.

\section{Opracowania}

Barnes T.D., The Collapse of the Homoeans in the East, „Studia Patristica” 1997, vol. XXIX, s. 3-16.

Barnes T.D., Constantine. Dynasty, Religion and Power in the Later Roman Empire, Oxford 2011.

Bradbury S., Julian's Pagan Revival and the Decline of Blood Sacrifice, „Phoenix” 1995, vol. XLIX, No. 4, s. 331-356. 
Bralewski S., Kanony kościelne $w$ sporze między Wschodem a Zachodem na tle schizmy antiocheńskiej $w$ IV wieku, „Acta Universitatis Lodziensis. Folia Historica" 2005, nr 80, s. 27-42.

Bralewski S., Symmachia Cesarstwa Rzymskiego z Bogiem chrześcijan (IV-VI wiek), t. I („Niezwykła przemiana” - narodziny nowej epoki), Byzantina Lodziensia XXVII, Łódź 2018.

Burns T.S., The Battle of Adrianople: A Reconsideration, „Historia. Zeitschrift für alte Geschichte" 1973, Bd. XXII, H. 2, s. 336-345.

The Cambridge Companion to the Age of Constantine, ed. N. Lenski, Cambridge 2006.

Cavallera F., Le schisme d'Antioche, Paris 1905.

Devreesse R., Le patriarcat d'Antioche depuis la paix de l'Église jusqu'à la conquête arabe, Paris 1945.

Drake H.A., Constantine and the Bishops: the Politics of Intolerance, Baltimore 2000.

Girardet K.M., Der Kaiser und sein Gott. Das Christentum im Denken und in der Religionspolitik Konstantins der Grosse, Berlin-New York 2010.

A Greek-English Lexicon, eds H.G. Liddell, R. Scott, Oxford 1996.

Heather P., Moncur D., Politics Philosophy and Empire in Fourth Century Select Orations of Themistius, Liverpool 2001.

Lançon B., Moreau T., Constantin. Un Auguste chrétien, Paris 2012.

Lenski N., Failure of Empire: Valens and the Roman State in the Fourth Century A.D., Berkeley-Los Angeles-London 2002.

Lenski N., Initium mali Romano imperio: Contemporary Reactions to the Battle of Adrianople, "Transactions of the American Philological Association" 1997, vol. CXXVII, s. 129-168.

Lenski N., Valens and the Monks: Cudgeling and Conscription as a Means of Social Control, „Dumbarton Oaks Papers” 2004, vol. LVIII, s. 93-117.

Liebeschuetz J.H.W.G., Antioch, City and Imperial Administration in the Later Roman Empire, Oxford 1972.

Maraval P., Constantin, empereur romain et chrétien, Paris 2011.

Marcone A., Costantino il Grande, Roma-Bari 2000.

Marrou H-I., L'Église de l'Antiquité tardive 303-604, Paris 1985.

Odahl Ch.M., Constantine and the Christian Empire, London-New York 2004.

Rutowski B., Bitwa pod Adrianopolem (9 VIII 378 r.) i jej nastepstwa, „Meander” 1978, R. XXXIII, s. 525-539.

Słownik grecko-polski, red. Z. Abramowiczówna, t. II, Warszawa 1960.

Słownik grecko-polski, t. I, oprac. O. Jurewicz, Warszawa 2000.

Słownik języka polskiego, red. W. Doroszewski, t. II, Warszawa 1960.

Snee R., Valens' Recall of the Nicene Exiles and Anti-Arian Propaganda, „Greek, Roman, and Byzantine Studies" 1985, vol. XXVI, s. 395-419.

Wilczyński M., Germanie w służbie zachodniorzymskiej wV w. n.e., Oświęcim 2018. Williams S., Friell G., Theodosius the Empire at Bay, London 2005, s. 152-156. 
SŁAWOMir BRALEWSKI

\title{
The strength and powerlessness of Emperor Walens, a zealous Christian and an enemy of Christians at the same time in Socrates of Constantinople's view
}

\begin{abstract}
E mperor Valens, who ruled in the years 364-378, is connected above all with E the fateful disaster suffered by the Roman army in the clash with the Goths at Adrianople on 9 August 378, in which he himself found death. Christians, supporters of the Nicene creed of 325, read his sudden death as God's punishment for the persecution of Orthodox Christians, whom they considered themselves to be. Socrates of Constantinople, author of Ecclesiastical History, which was a continuation of the work of Eusebius of Caesarea, noticed a contradiction in the conduct of Emperor Valens. The historian saw in him both an ardent Christian, who was zealous in his faith, and an enemy of Christians, who waged war against them. This contradiction was attributed by Socrates to the ruler himself, who, though convinced of his great religious zeal, had nothing to do with the principles of the Christian religion, which he should follow. As for the strength and powerlessness of the title, it must be said that Socrates of Constantinople believed that the power of Emperor Walens was only apparent, although much Christian blood was shed on his command. The powerlessness of this ruler was first exposed by the Christians persecuted by him, and ultimately by God himself, sending various cataclysms to the Roman Empire, and to Walens himself a death unworthy of the emperor without his due burial.
\end{abstract}

Keywords: Emperor Valens, Socrates of Constantinople, battle of Adrianople. 